\title{
Development of a Group Decision Support System with the Multi-Stage Multi- Attribute Group Decision Making (MS-MAGDM) Method on the Intelligent Warehouse Management System
}

Pengembangan Sistem Pendukung Keputusan Kelompok dengan Metode Multi-Stage MultiAttribute Group Decision Making ( MS-MAGDM ) pada Intelligent Warehouse Management System

\section{Simon Pulung Nugroho ${ }^{1}$}

${ }^{1}$ Informatika, Universitas Pembangunan Nasional Veteran Yogyakarta, Indonesia

1*simon.pulung@upnyk.ac.id

*: Penulis korenspondensi (corresponding author)

\section{Informasi Artikel}

Received: April 2021

Revised: April 2021

Accepted: May 2021

Published: August 2021

\begin{abstract}
Purpose: to find a solution with MS-DAGDM for the problem of different criteria used by decision maker at each stage.
\end{abstract}

Design/methodology/approach: This research was conducted using literature review with a study of the theory of decision-making methods, group decisions, suplier selection processes, and factors that influence decisions in the context of warehousing and MS-MAGDM to solve the problems.

Findings/result: This research find that GDSS prototypes which have four methods in making decisions. First, Analytical Hierarchy Process for weighting the division head level. Second, TOPSIS for divison head level decisions. Third, Hybrid Weight Averaging (HWA) manager level. Fourth, Time Weight Averaging (TWA) for manager level decisions.

Originality/value/state of the art:

The decision-making model of the GDSS system in this study combines four methods at each level of management. The section head level uses AHP for the level weighting and TOPSIS for decision making. Level managers use Hybrid Weight Averaging (HWA) weighting and Time Weight Averaging (TWA) for decisions. The combination of these methods is carried out using a Poisson distribution, for HWA and TWA operators to combine individual decisions into group decisions. 
Keywords: group decision support system; multi-stage; decision making; Hybrid Weight Averaging (HWA);

Time Weight Averaging (TWA)

Kata kunci: group decision support system; multi-stage; decision making; Hybrid Weight Averaging (HWA); Time Weight Averaging (TWA)

\begin{abstract}
Abstrak
Tujuan: Fokus penelitian ini adalah mencari solusi dengan MS-MAGDM untuk permasalahan perbedaan kriteria yang dipergunakan pembuat keputusan dalam setiap stage.

Perancangan/metode/pendekatan: Metode yang digunakan yaitu kajian kepustakaan dengan kajian terhadap teori metode pembuatan keputusan, keputusan kelompok, proses pemilihan supplier, dan faktor yang berpengaruh pada keputusan dalam konteks pergudangan serta MSMAGDM untuk menyelesaikan permasalahan tersebut.

Hasil: Hasil penelitian ini berupa purwarupa GDSS yang memiliki 4 metode dalam pembuatan keputusan yaitu Analytical Hierarchi Process (AHP) untuk pembobotan level kepala bagian, TOPSIS untuk keputusan level kepala bagian, Hybrid Weight Averaging (HWA) pembobotan pada level manager dan Time Weight Averaging (TWA) untuk keputusan level manager

Keaslian/ state of the art:

Model pengambilan keputusan sistem GDSS penelitian ini menggabungkan 4 metode pada setiap tingkatan manajemen. Level kepala bagian menggunakan AHP untuk pembobotan level dan TOPSIS untuk pembuatan keputusan. Level manager menggunakan Hybrid Weight Averaging (HWA) pembobotan dan Time Weight Averaging (TWA) untuk keputusan. Penggabungan metode dilakukan menggunakan distribusi Poisson, untuk operator HWA dan TWA guna memadukan keputusan individu mejadi keputusan kelompok.
\end{abstract}

\section{Pendahuluan}

Intelligent Warehouse Management System (i-WMS) merupakan solusi terintegrasi yang dipergunakan untuk memecahkan masalah integrasi dan otomasi pergudangan. i-WMS mengembangkan model integrasi dari setiap proses yang terdapat dalam transaksi pergudangan. Model integrasi yang dikembangkan bertujuan supaya sumber daya data pergudangan menjadi lebih efisien, sehingga mampu menjaga mutu dan kualitas barang. Selain itu, i-WMS memanfaatkan beberapa model artificial intelligent untuk mengembangkan otomasi transaksi. Arsitektur i-WMS tersusun dari lima subsistem yaitu (1) Executive Sumarry Report (ESR) berfungsi sarana pembantu pengambil keputusan di tingkat manajerial (2) Adaptive Warehouse System (AWS) berfungsi tempat penyimpanan untuk mempertahankan kualitas barang sebelum didistribusikan, (3) Intelligent Forecasting System (IFS) berfungsi melakukan peramalan penjualan barang dan hasil yang didapatkan digunakan sebagai acuan untuk melakukan pembelian barang ke supplier, (4) Real-Time Transportation Monitoring System (RTMS) berfungsi melakukan pengawasan armada pengiriman dan distribusi barang dari sumber ke tempat tujuan dan sistem ini menjadi fokus penelitian yang akan dilakukan, (5) Intelligent 
Logistic System (ILS) berfungsi mengendalikan proses logistik dari warehouse sampai ke lokasi pelanggan [1].

Salah satu komponen i-WMS adalah Executive Summary Report, dimana sub sistem ini mengakomodasi kebutuhan pembuat kebijakan untuk menentukan langkah organisasi selanjutnya. Salah satu kemampuan dari sub sistem ini tentunya adalah membuat rekomendasi keputusan antar pengambil keputusan [1][2].

Permasalahan dalam manajemen pergudangan yang membutuhkan banyak pertimbangan adalah pemilihan supplier. Manajemen supplier merupakan isu kunci dari rantai manajemen pasok karena biaya bahan baku dan komponen merupakan biaya utama dari produk dan sebagian besar perusahaan menghabiskan cukup banyak menghabiskan biaya pada pembelian bahan baku. Oleh karena itu, pemilihan supplier adalah salah satu masalah pengambilan keputusan yang paling penting, karena pemilihan supplier yang tepat mendukung penghematan pengeluaran perusahaan, terutama pada perusahaan yang menghabiskan sebagian pengeluarannya untuk pembelian bahan baku [3]

Dari permasalahan tersebut solusi yang ditempuh yaitu membangun Group Decision Support System (GDSS). Solusi GDSS ditempuh untuk mengatasi permasalahan jika anggota kelompok pengambil keputusan memiliki sudut pandang yang berbeda, untuk menggabungkan beberapa preferensi dan mendamaikan perbedaan ide. Untuk mencapai tersebut dapat digunakan Multi-Criteria Decision Making (MCDM), dimana metode ini telah dikembangkan untuk memecahkan preferensi yang saling bertentangan antara kriteria untuk pembuatan keputusan tunggal $[4][5][6]$.

[7] mengungkapkan bahwa pendekatan multi-stage telah banyak dipakai dalam investigasi keputusan, diagnosa medis, efisiensi sistem militer dan lain-lain. Penelitian ini ditujukan untuk melakukan investigasi model Multi-Stage Multi-Multi Attribute Group Decision Making (MS-MAGDM). Adapun permasalahan yang menjadi focus penelitian adalah pembobotan atribut dan alternatif berhingga terhadap data atribut yang dikumpulkan pada tahap berbeda. [7][8][9][10][11] menggunakan Distribusi Poisson untuk menentukan Time-Weighted Averaging (TWA) operator. Dari latar belakang belakang masalah dan paparan konsep solusi yang mungkin dilakukan penelitian ini fokus pada Pengembangan Sistem Pendukung Keputusan Kelompok dengan Metode Multi-Stage Multi-Attribute Group Decision Making (MS-MAGDM).

Strategi pengambilan keputusan dalam organisasi dilakukan dengan melalui evaluasi serangkaian alternatif solusi yang ada dan memilih salah satu alternatif terbaik berdasarkan informasi yang tersedia serta pandangan perspektif dari pengambil keputusan. [12] dalam penelitian evaluasi supplier dan manajemen perusahaan manufaktur, mengembangkan sistem Goal Programming (FGP).

[10] mengaplikasikan metode TOPSIS dalam lingkungan pengembangan model Sistem Pendukung keputusan kelompok. Dalam penelitian ini peringkat setiap alternatif dan bobot menggunakan model linguistik dan direpresentasikan dalam kurva segitiga. Kemudian dengan menggunakan metode vertex menghitung jarak kedekatan antara 2 bilangan dalam kurva segitiga.

[13] dan [14] mengemukakan salah satu pemodelan GDSS adalah rational political group decision model dimana model tersebut didasarkan pada tujuan, alternatif, konsekuensi 
dan optimalitas. Model ini mengasumsikan bahwa informasi yang dimiliki lengkap untuk setiap keputusan yang dapat diambil dan menggunakan konsepsi yang benar untuk menentukan keputusan. [15] menggunakan tiga faktor ketidakpastian untuk keputusan multi-level dan multikriteria guna menghasilkan keputusan yang memuaskan semua pengambil keputusan. Dimana solusi yang diberikan adalah solusi yang memiliki derajat / bobot yang paling tinggi. Dengan algoritma Fuzzy Multi Criteria Group Decision Making, sistem yang dibangun dapat membantu melakukan analisa ketidakpastian keputusan multi kriteria dalam melakukan studi jangka panjang untuk kebijakan [15][16][17][18].

[19] mengungkapkan bahwa Sistem Pendukung keputusan tradisional (termasuk juga GDSS) harus menggunakan lokasi tertentu atau bahkan menggunakan ruang pertemuan khusus. Penelitian-penelitian tentang penggunaan teknologi web untuk mengembangkan DSS saat ini terus berkembang seperti antara lain, [20] mengembangkan Collaborative Recommender Systems berbasis web DSS untuk melakukan analisis kemampuan siswa, sikap, preferensi dan lain sebagainya.

[21] mengusulkan pendekatan baru metode perangkingan bilangan dengan menggunakan metode distance metric. Dalam kajiannya metode tersebut dibandingkan dengan model peringkat intuisi, metode mean/spread value. Kasus yang diangkat pada penelitian ini adalah pemilihan personel sistem informasi, dimana setiap kandidat diberikan kriteria dan sub kriteria tertentu, kemudian kelompok pengambil keputusan memberikan penilaian yang dirangkum dalam sebuah matrik keputusan dan dengan menggunakan bobot yang diberikan menggabungkan penilaian tersebut.

[22][13][23]mengusulkan Choquet ordered averaging (NDINCOA) operator, dimana operator ini menggunakan jumlah selang distribusi normal Choquet untuk mencari nilai ratarata operator. Operator NDINCOA tidak hanya mempertimbangkan tingkat kepentingan elemen, tetapi juga mencerminkan korelasi antara elemen. Menurut [7] kajian MAGDM saat ini cukup maju namun kebanyakan pendekatan hanya berfokus pada argument input yang dikumpulkan pada tahap yang sama. Penelitian ini merupakan kajian baru dalam pembuatan bobot dengan distribusi Poisson, menggunakan HWA dan TWA operator untuk memadukan keputusan individu mejadi keputusan kelompok. Penelitian ini menggunakan aturan distribusi (Poisson dan normal) untuk menentukan bobot dari kelompok pengambil keputusan ataupun bobot pada setiap stage.

\section{Metode/Perancangan}

Metode pendekatan Multi-Stage Multi Atribute Group Decision Making ( MS-MAGDM ) yang dipergunakan mempertimbangkan bobot waktu pengambilan data atribut kriteria. Metode berfokus masalah multi tahap pengambilan keputusan seperti : keputusan investasi, diagnosa medis, penilaian personil dinamis, sistem evaluasi kinerja dan performance. Keterbaruan penelitian ini adalah penentuan bobot dengan Poison Distribution, menggunakan Hybrid Weight Agregation (HWA) operator dan Time Weighted Averaging (TWA) untuk memadukan penilaian pembuat keputusan individu dan opini masing-masing serta kelompok.

[7] memperkenalkan Time-Weighted Averaging operator sebagai berikut :

$$
\mathrm{TWA}_{\mathrm{w}(\mathrm{s})}\left(\mathrm{a}\left(\mathrm{S}_{1}\right), \mathrm{a}\left(\mathrm{S}_{2}\right), \ldots, \mathrm{a}\left(\mathrm{S}_{\mathrm{p}}\right)=\sum_{k=1}^{p} W\left(S_{k}\right) a\left(S_{k}\right)\right.
$$


Dimana $W(s k) \geq 0, k=1,2, \ldots, p, \sum_{k=1}^{p} W(s k)=1$

Dimana $\quad$ TWA $_{\mathrm{w}(\mathrm{s})}=$ Nilai Time-Weighted Averaging

$W\left(S_{k}\right)=$ merupakan bobot pada Stage ke k

$a\left(S_{k}\right)=$ merupakan keputusan pada pada Stage ke k

Pendekatan ini mempertimbangkan perbedaan stage yang memiliki perbedaan bobot. Distribusi bobot pada setiap stage dapat diberikan probabilitas diskret. Distribusi bobot yang dipergunakan pada MS-MAGDM menggunakan Distribusi Poison. Distribusi ini menggunakan percobaan yang dilakukan sebanyak N kali menghasilkan peubah acak X. Pertimbangan menggunakan distribusi Poisson adalah lebih mudah memahami dan dapat memecahkan masalah dari peluangpeluang yang jarang terjadi, misal menghitung kerusakan suatu produk yang akan diproduksi. Manfaat dari penggunaan distribusi poisson dalam dunia industri adalah agar meminimalkan peluang kerusakan atau kecacatan suatu produk dalam produksi. Ketentuan dari distribusi Poison adalah sebagai berikut :

1. Jumlah keberhasilan dalam dua interval waktu menguraikan (atau wilayah ruang) adalah independen

2. Probabilitas sukses selama interval waktu kecil atau daerah ruang sebanding dengan seluruh panjang interval waktu atau wilayah ruang.

Dalam pendekatan ini penyesuaian pendekatan distribusi Poison untuk MS-MAGDM adalah sebagai berikut :

$$
W(s k)=\frac{\frac{\lambda^{k}}{k !} e^{-\lambda}}{\sum_{k=1}^{p} \frac{\lambda^{k}}{k !} e^{-\lambda}}=\frac{\frac{\lambda^{k}}{k !}}{\sum_{k=1}^{p} \frac{\lambda^{k}}{k !}}, \lambda>0, \mathrm{k}=1,2, \ldots, \mathrm{p}
$$

Dimana parameter $\lambda$, dalam aplikasi praktis ditentukan sebelum pengambil keputusan memberikan bobot pada setiap kriteria keputusan. [7]mengungkapkan dari beberapa aksperimen numerik ditemukan bahwa $\lambda$ dapat diambil dari interval $\left[\begin{array}{lll}1 & \ldots & 10\end{array}\right]$. Adapun beberapa hasil eksperimen tersebut, tersaji dalam tabel dibawah ini :

Tabel 1 Bobot Vektor $\omega(\mathrm{s})$ dengan $\lambda=1,2, \ldots, 10$ dan $p=2$

\begin{tabular}{lllllllllll}
\hline $\mathbf{p = 2}$ & $\boldsymbol{\lambda}=\mathbf{1}$ & $\boldsymbol{\lambda = \mathbf { 2 }}$ & $\boldsymbol{\lambda}=\mathbf{3}$ & $\boldsymbol{\lambda}=\mathbf{4}$ & $\boldsymbol{\lambda = 5}$ & $\boldsymbol{\lambda = 6}$ & $\boldsymbol{\lambda = 7}$ & $\boldsymbol{\lambda = \mathbf { 8 }}$ & $\boldsymbol{\lambda}=\mathbf{9}$ & $\boldsymbol{\lambda}=\mathbf{1 0}$ \\
\hline$\omega(\mathrm{s} 1))$ & 0.667 & 0.500 & 0.400 & 0.333 & 0.286 & 0.250 & 0.222 & 0.200 & 0.182 & 0.167 \\
$\omega(\mathrm{s} 2)$ & 0.333 & 0.500 & 0.600 & 0.667 & 0.714 & 0.750 & 0.778 & 0.800 & 0.818 & 0.833 \\
\hline
\end{tabular}

Tabel 2 Bobot Vektor $\omega(\mathrm{s})$ dengan $\lambda=1,2, \ldots, 10$ dan $\mathrm{p}=3$

\begin{tabular}{lcccccccccc}
\hline $\mathbf{p = 3}$ & $\boldsymbol{\lambda}=\mathbf{1}$ & $\boldsymbol{\lambda}=\mathbf{2}$ & $\boldsymbol{\lambda}=\mathbf{3}$ & $\boldsymbol{\lambda}=\mathbf{4}$ & $\boldsymbol{\lambda}=\mathbf{5}$ & $\boldsymbol{\lambda}=\mathbf{6}$ & $\boldsymbol{\lambda}=\mathbf{7}$ & $\boldsymbol{\lambda}=\mathbf{8}$ & $\boldsymbol{\lambda}=\mathbf{9}$ & $\boldsymbol{\lambda}=\mathbf{1 0}$ \\
\hline$\omega(\mathrm{s} 1)$ & 0.600 & 0.375 & 0.250 & 0.176 & 0.130 & 0.100 & 0.079 & 0.064 & 0.053 & 0.044 \\
$\omega(\mathrm{s} 2)$ & 0.300 & 0.375 & 0.375 & 0.353 & 0.326 & 0.300 & 0.276 & 0.255 & 0.237 & 0.221 \\
$\omega(\mathrm{s} 3)$ & 0.100 & 0.250 & 0.375 & 0.471 & 0.543 & 0.600 & 0.645 & 0.681 & 0.710 & 0.735 \\
\hline
\end{tabular}


Tabel 3 Bobot Vektor $\omega(\mathrm{s})$ dengan $\lambda=1,2, \ldots, 10$ dan $\mathrm{p}=4$

\begin{tabular}{lllllllllll}
\hline $\mathbf{p = 4}$ & $\boldsymbol{\lambda}=\mathbf{1}$ & $\boldsymbol{\lambda}=\mathbf{2}$ & $\boldsymbol{\lambda = 3}$ & $\boldsymbol{\lambda}=\mathbf{4}$ & $\boldsymbol{\lambda}=\mathbf{5}$ & $\boldsymbol{\lambda}=\mathbf{6}$ & $\boldsymbol{\lambda}=\mathbf{7}$ & $\boldsymbol{\lambda}=\mathbf{8}$ & $\boldsymbol{\lambda}=\mathbf{9}$ & $\boldsymbol{\lambda}=\mathbf{1 0}$ \\
\hline$\omega(\mathrm{s} 1)$ & 0.585 & 0.333 & 0.195 & 0.120 & 0.078 & 0.053 & 0.037 & 0.027 & 0.020 & 0.016 \\
\hline$\omega(\mathrm{s} 2)$ & 0.293 & 0.333 & 0.293 & 0.240 & 0.194 & 0.158 & 0.130 & 0.108 & 0.091 & 0.078 \\
\hline$\omega(\mathrm{s} 3)$ & 0.098 & 0.222 & 0.293 & 0.320 & 0.324 & 0.316 & 0.303 & 0.288 & 0.273 & 0.259 \\
\hline$\omega(\mathrm{s} 4)$ & 0.024 & 0.111 & 0.220 & 0.320 & 0.405 & 0.474 & 0.530 & 0.577 & 0.615 & 0.648 \\
\hline
\end{tabular}

Tabel 4 Bobot Vektor $\omega(\mathrm{s})$ dengan $\lambda=1,2, \ldots, 10$ dan $\mathrm{p}=5$

\begin{tabular}{ccccccccccc}
\hline $\mathbf{p = 4}$ & $\boldsymbol{\lambda}=\mathbf{1}$ & $\boldsymbol{\lambda = \mathbf { 2 }}$ & $\boldsymbol{\lambda}=\mathbf{3}$ & $\boldsymbol{\lambda}=\mathbf{4}$ & $\boldsymbol{\lambda}=\mathbf{5}$ & $\boldsymbol{\lambda}=\mathbf{6}$ & $\boldsymbol{\lambda}=\mathbf{7}$ & $\boldsymbol{\lambda}=\mathbf{8}$ & $\boldsymbol{\lambda}=\mathbf{9}$ & $\boldsymbol{\lambda}=\mathbf{1 0}$ \\
\hline$\omega(\mathrm{s} 1)$ & 0.583 & 0.319 & 0.172 & 0.096 & 0.055 & 0.034 & 0.021 & 0.014 & 0.010 & 0.007 \\
\hline$\omega(\mathrm{s} 2)$ & 0.291 & 0.319 & 0.259 & 0.191 & 0.138 & 0.101 & 0.075 & 0.056 & 0.043 & 0.034 \\
\hline$\omega(\mathrm{s} 3)$ & 0.097 & 0.213 & 0.259 & 0.255 & 0.230 & 0.202 & 0.174 & 0.150 & 0.130 & 0.113 \\
\hline$\omega(\mathrm{s} 4)$ & 0.024 & 0.106 & 0.194 & 0.255 & 0.288 & 0.303 & 0.304 & 0.300 & 0.292 & 0.282 \\
\hline$\omega(\mathrm{s} 5)$ & 0.005 & 0.043 & 0.116 & 0.204 & 0.288 & 0.360 & 0.426 & 0.480 & 0.525 & 0.564 \\
\hline
\end{tabular}

Dalam proses pengambilan keputusan, apabila terdapat beberapa pembuat keputusan memberikan argumen preferensi terlalu tinggi atau terlalu rendah untuk sesuatu disukai atau tidak disukai. [7] mengembangkan metode berdasarkan posisi untuk membedakan prefensi yang terlalu tinggi atau terlalu rendah. Penggunaan operator HWA dapat menyeimbangkan pengambil keputusan dan mengurangi pengaruh argumen yang tidak adil pada hasil keputusan dengan menggunakan distribusi normal.

$r_{j}(s k)=H W A\left(r_{j}\left(S_{k}^{(1)}\right), r_{j}\left(S_{k}^{(1)}\right), \ldots, r_{j}\left(S_{k}^{(q)}\right)\right)=\sum_{l=1}^{q} V_{l} r_{j}\left(S_{k}^{(l)}\right.$

Dimana :

$\mathrm{V}=\left(\mathrm{V}_{1}, \mathrm{~V}_{2}, \ldots \mathrm{V}_{\mathrm{q}}\right)$ adalah vektor bobot yang dibangun dari distribusi normal

Langkah - langkah untuk melakukan pengolahan keputusan dengan menggunakan MSMAGDM sebagai berikut :

1. Agregasi nilai atribut di kolom $\mathrm{j}$ dari $\mathrm{R}\left(S_{k}^{(l)}\right)$ yang disediakan oleh pengambil keputusan pada suatu stage dengan menggunakan operator WA

2. Menggunakan operator HWA menjadi vektor bobot, yang diperoleh dengan distribusi normal metode berdasarkan agregat nilai $\mathrm{r}_{\mathrm{j}}\left(S_{k}^{(l)}\right)(1=1,2,3)$ yang disediakan oleh semua pengambil keputusan $d_{1}(l=1,2,3)$, dan mendapatkan $r_{j}$ nilai atribut keseluruhan $\mathrm{r}_{\mathrm{j}}\left(\mathrm{s}_{\mathrm{k}}\right)$ dari alternatif $\mathrm{x}_{\mathrm{j}}$ pada tahap suatu stage

3. Menggunakan operator TWA untuk memadukan nilai-nilai $r_{j}\left(s_{k}\right)(k=1,2,3)$ dari semua tahapan $\mathrm{s}_{\mathrm{k}}(\mathrm{k}=1,2,3)$ ke dalam nilai $\mathrm{r}_{\mathrm{j}}$ kompleks sesuai dengan $\mathrm{Xj}$

4. Peringkat semua alternatif $X_{j}(j=1,2, \ldots, 5)$ sesuai dengan nilai-nilai $r_{j}(j=1,2, \ldots, 5)$ 


\section{Hasil dan Pembahasan}

Pada penelitian untuk skenario pengujian menggunakan pencocokan hasil pengolahan data pada contoh kasus dan prototipe yang dihasilkan sehingga dapat dapat diverifikasi sesuai model MS-MAGDM yang dikembangkan. Contoh kasus yang dipergunakan, Perusahaan memilih 5 kandidat supplier tempe CV. Nyamik Legi ( S006 ), CV. Kampung Manis (S007 ), CV. Sekar Bati (S008 ) CV. Rasa Kuwe (S009 ), CV. Waras Amanah (S010 ). Evaluasi kinerja diberikan pada performa 3 tahun kebelakang yaitu tahun 2010 (Stage 1), tahun 2011 (Stage 2) dan tahun 2012 (stage 3 ) dengan bobot 0.1; 0.3; 0.6 ( diambil dari distribusi poison dengan nilai $\lambda=6$ ). Pengujian dalam Gambar 1 menunjukkan projek 2 diberikan judul projek pemilihan supplier tempe, dengan memasukkan nama supplier sesuai studi kasus

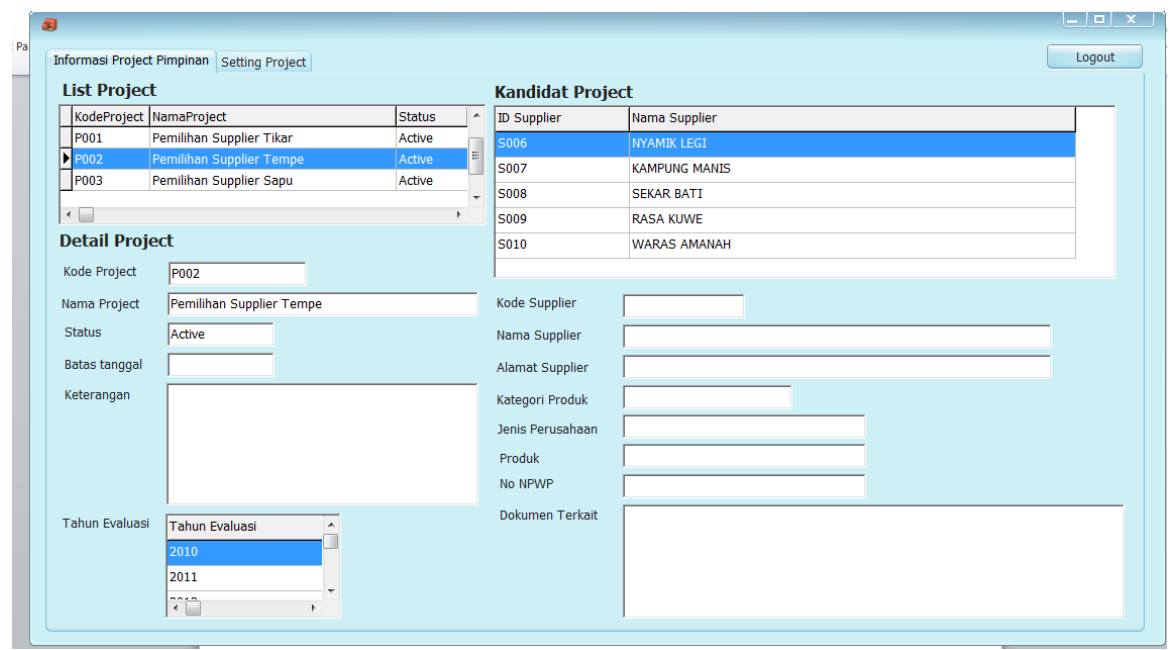

Gambar 1 Pengujian Pemilihan alternatif ( Supplier ) pada suatu project

Masing-masing kepala bagian memberikan kriteria untuk penilaian alternatif. Kepala Bagian Keuangan memberikan kriteria Harga produk, Biaya transportasi, Pajak, dan Analisis biaya. Hasil pengujian sistem pada input kriteria bagian keuangan terlihat pada gambar 2 .

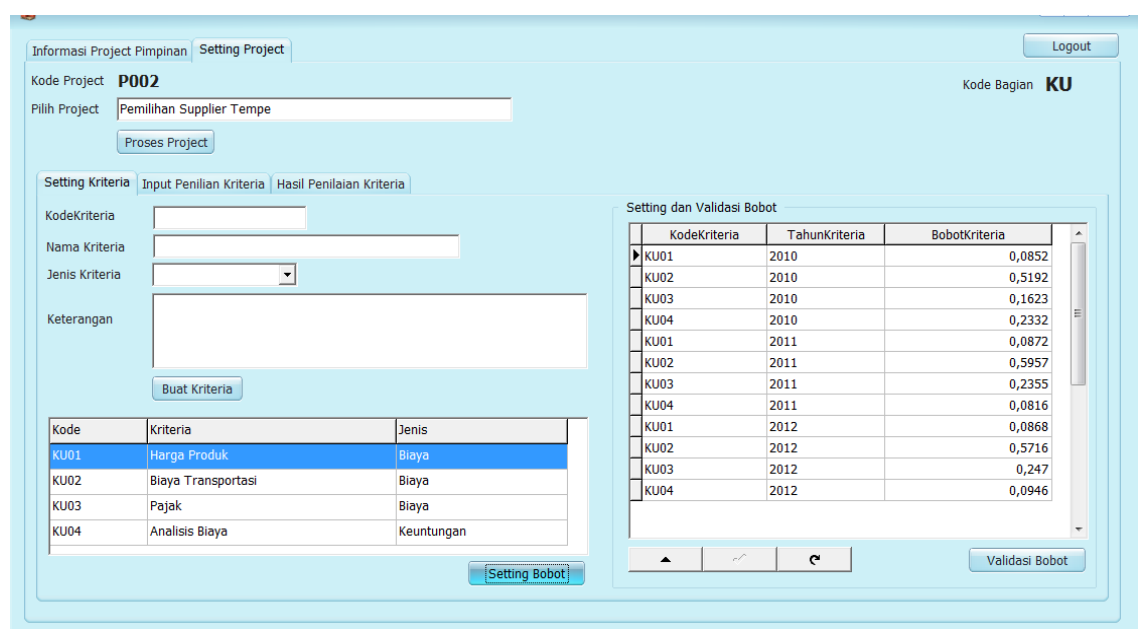

Gambar 2 Pengujian input kriteria pada bagian keuangan

Setelah masing-masing kepala bagian memberikan kriteria maka top manager akan memberikan bobot masing-masing kriteria pada masing-masing stage. Pemberian bobot ini 
menggunakan metode AHP [24][25][26][27]. Pemberian bobot dengan AHP tersaji dalam tabel 5. Dalam pengujian sistem terlihat dalam gambar 3.

Setelah dilakukan pembobotan maka selanjutnya Kepala Bagian memberikan penilaian terhadap setiap alternatif yang akan dinilai pada setiap stagenya. Pada pengujian mengambil data sampel dari Kepala bagian Regulasi Produk pada stage (tahun) 2010 (tabel 6).

Tabel 5. Pemberian bobot kriteria

\begin{tabular}{cccc}
\hline & RP01 & RP02 & RP03 \\
\hline RP01 & 1 & 4 & 2 \\
\hline RP02 & 0,25 & 1 & 4 \\
\hline RP03 & 0,5 & 0,25 & 1 \\
\hline
\end{tabular}

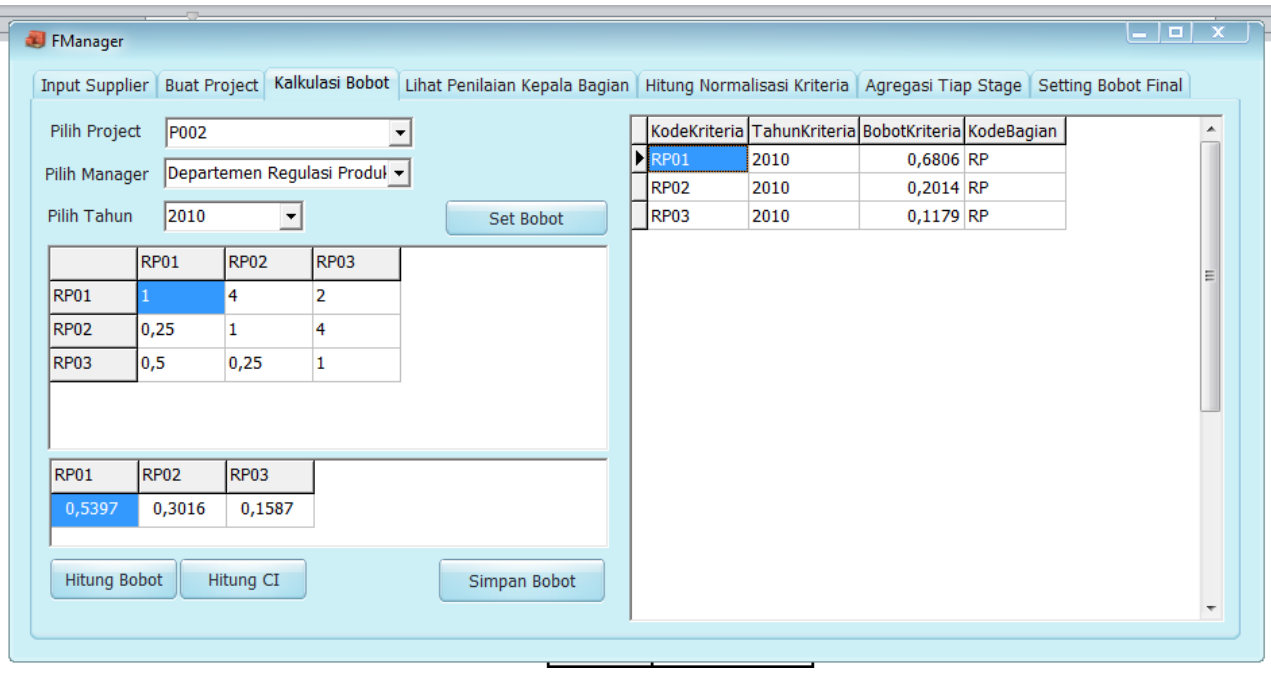

Gambar 3. Pengujian Pembobotan dengan metode AHP

Tabel 6. Pemberian bobot kriteria

\begin{tabular}{llll}
\hline Alternatif & $\begin{array}{l}\text { ketepatan } \\
\text { pengiriman }\end{array}$ & klaim garansi & Tingkat retur produk \\
\hline A1 & 4 & 7 & 5 \\
\hline A2 & 2 & 4 & 10 \\
\hline A3 & 3 & 6 & 8 \\
\hline A4 & 3 & 4 & 6 \\
\hline A5 & 4 & 5 & 3 \\
\hline
\end{tabular}

Adapun bobot yang sudah dibuat oleh Top Manager dengan AHP akan dipergunakan untuk pembuatan keputusan pada kepala bagian. Implementasi pada sistem dengan menggunakan metode TOPSIS [28][29][30][31][32][33]. Pada kepala bagian regulasi produk untuk menghitung matrik terbobot pada kepala bagian regulasi produk tersaji dalam gambar 4 . 


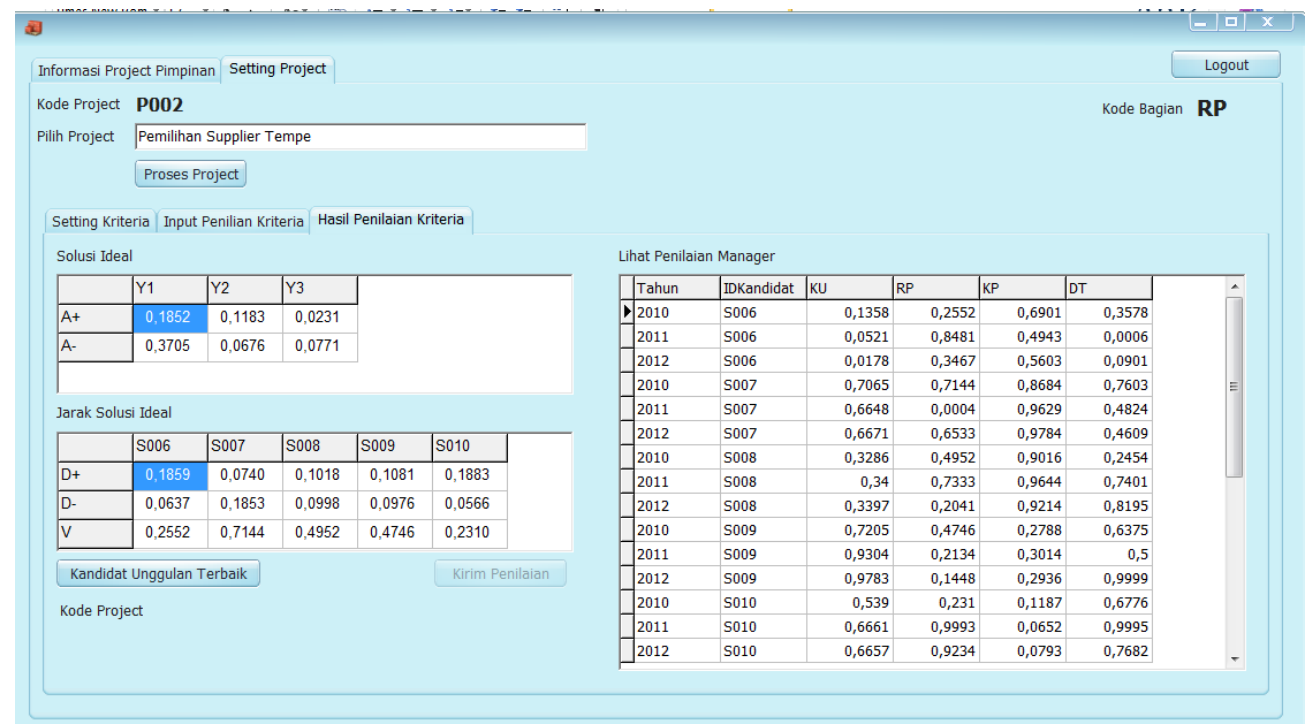

Gambar 4 Pengujian sistem untuk menampilkan hasil perhitungan TOPSIS pada Kepala Bagian Regulasi Produk untuk tahun 2010

Selanjutnya setelah setiap kepala bagian melengkapi tabel Tahun Evaluasi (Penilaian Manager) maka Top manager akan melakukan perhitungan bobot distribusi normal untuk memperoleh bobot dari kriteria utama yang akan digunakan (Gambar 5). Adapun nilai distribusi normal diambil dari Tabel Distribusi Normal Standard Z.

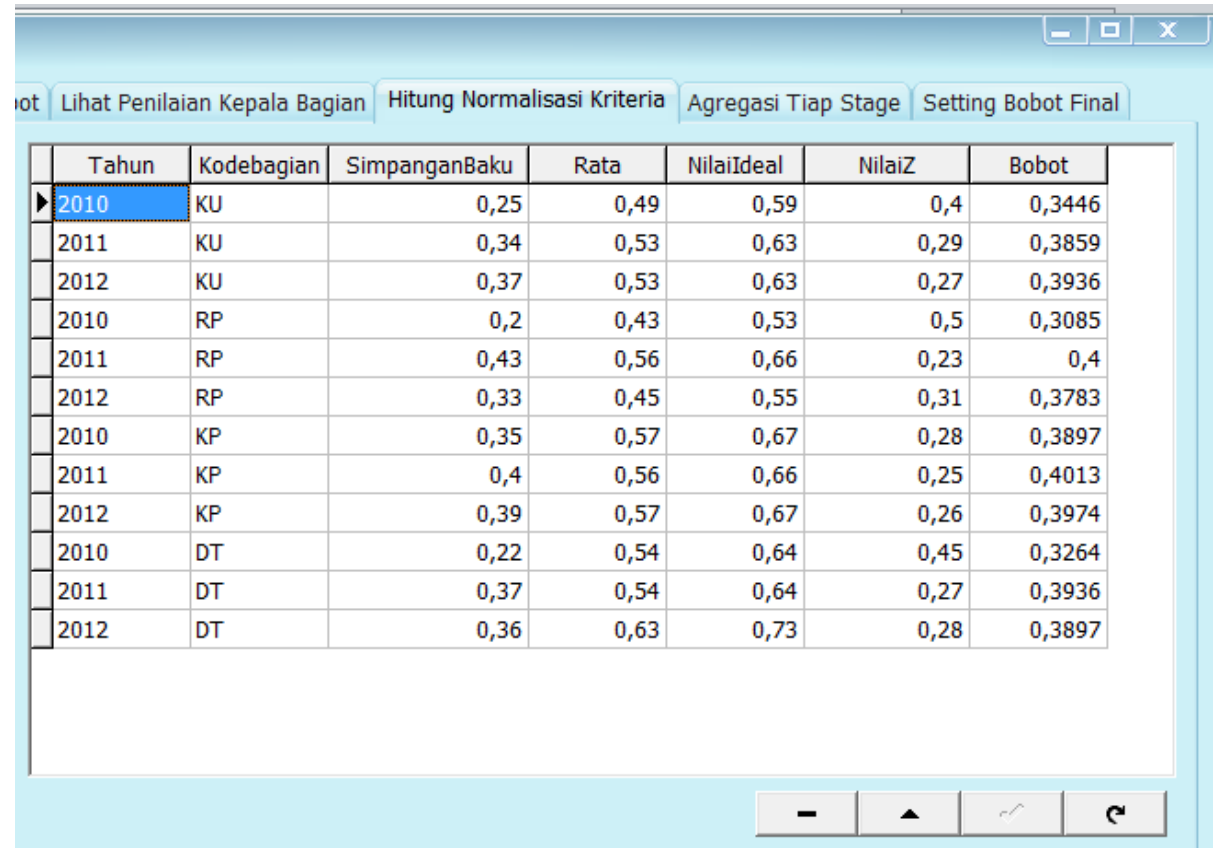

Gambar 5. Pengujian sistem untuk menampilkan hasil nilai $\mathrm{Z}$ guna mendapatkan distribusi normal 
Langkah berikut Top Manager melakukan agregasi stage (Gambar 6) untuk mendapatkan nilai kinerja dari masing-masing supplier pada setiap tahun / stage.

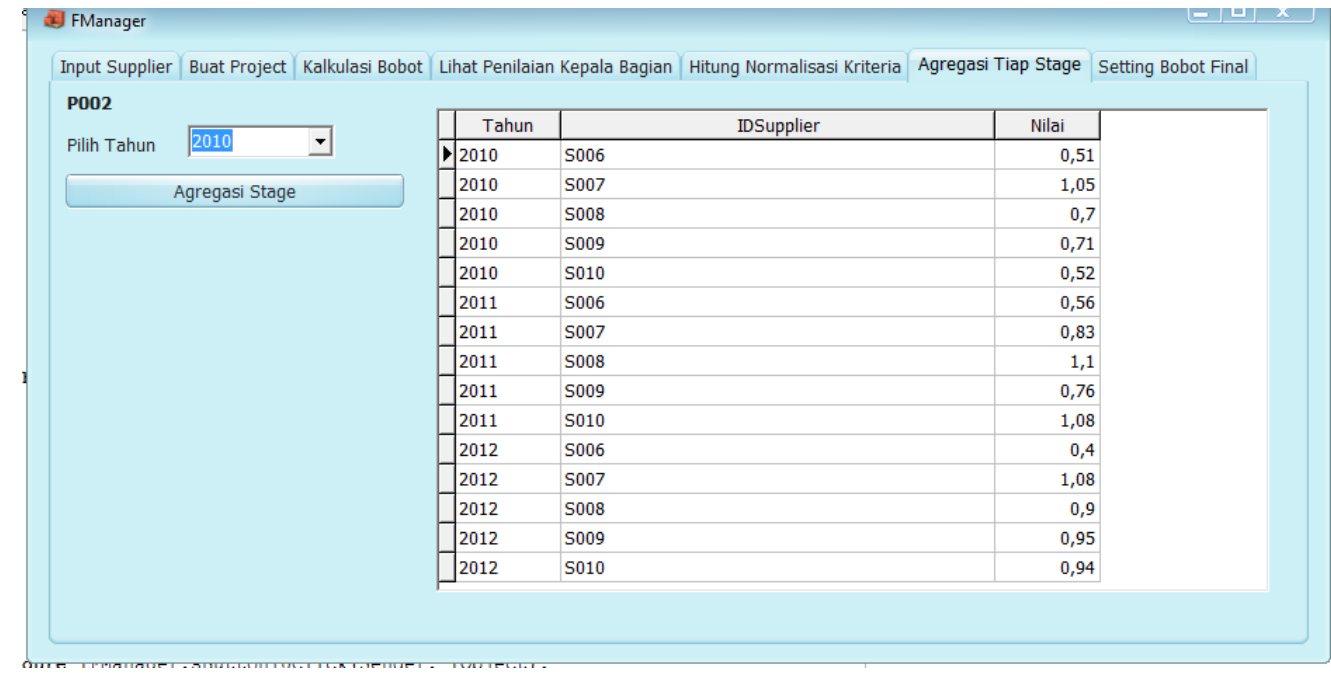

Gambar 6. Pengujian sistem untuk menampilkan hasil penilaian alternatif pada masing-masing tahun

Langkah terakhir adalah Top manager memberikan bobot pada masing-masing stage dengan menggunakan distribusi poisson dengan bobot $0.1 ; 0.3 ; 0.6$ (diambil dari distribusi poison dengan nilai $\lambda=6)($ Gambar 7)

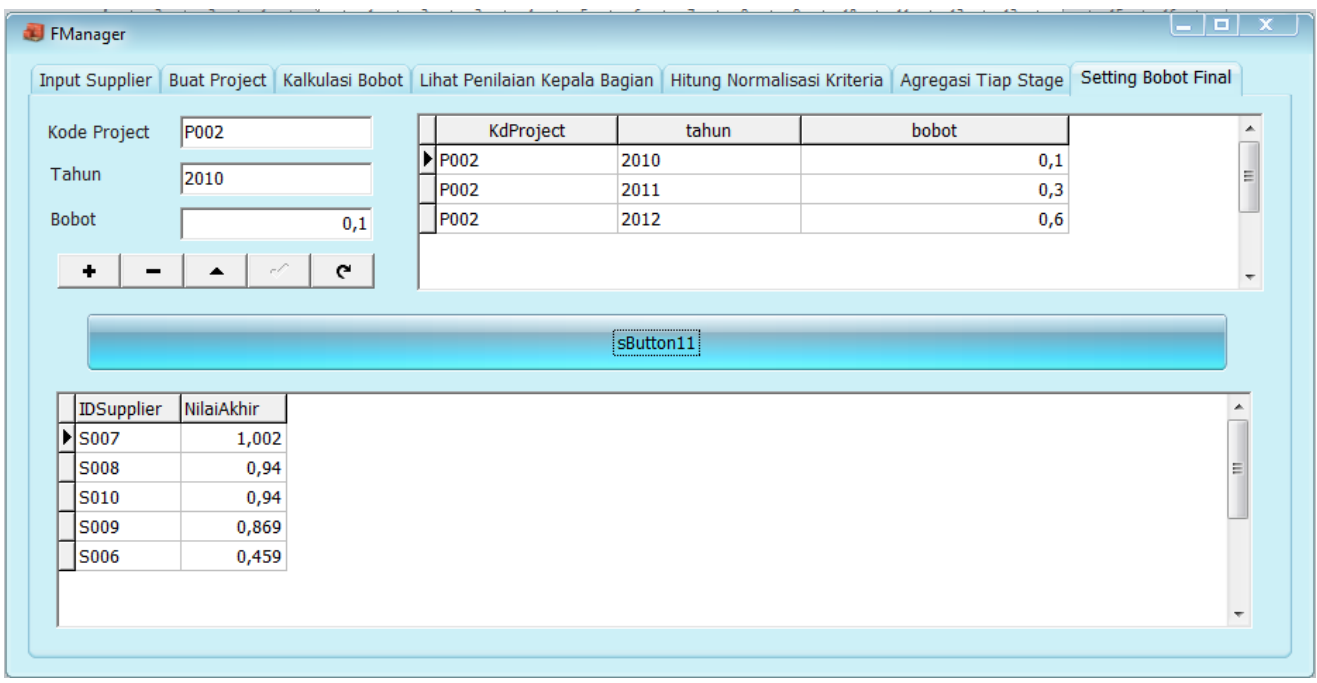

Gambar 7. Pengujian sistem untuk menampilkan hasil penilaian akhir sistem dengan menggunakan bobot distribusi Poisson

\section{Kesimpulan dan Saran}

Berdasarkan analisis dan fungsional pengujian aplikasi ini, dapat disimpulkan empat hal. Pertama, sistem MS-MAGDM sangat diperlukan ketika cakupan pembuatan keputusan adalah evalusi kinerja yang berkelanjutan. Kedua, prototype MS-MAGDM dibuat dengan tujuan untuk melatih manajer bagian membuat nilai keputusan sesuai kompetensinya dan berdasarkan kepada data. Ketiga, prototype MS-MAGDM dapat mengakomodir kebebasan 
masing-masing pembuat keputusan untuk menentukan kriteria dan bobotnya masing-masing. Keempat, algoritma MS-MAGDM dapat diimplementasikan sebagai model sistem pembuatan keputusan dimana masing-masing pembuat keputusan dapat bebas memberikan cara pandang sesuai dengan jabatan dan kompetensinya.

Penelitian selanjutnya sebaiknya meneliti mengenai evaluasi implementasi pencarian solusi dengan MS-MAGDM untuk permasalahan perbedaan kriteria yang dipergunakan pembuat keputusan dalam setiap stage.

\section{Daftar Pustaka}

[1] R. Pulungan, S. P. Nugroho, N. El Maidah, T. B. Atmojo, P. D. Hardo, and P. Pawenang, "Design of an Intelligent Warehouse Management System," Inf. Syst. Int. Conf., pp. 263268, 2013, doi: 10.1007/s11277-017-5199-7.

[2] M. Tukai, A. George, P. Delamare, C. K. Toure, A. Tounkara, and A. Dembele, "Report on strengthening the warehouse management system for the pharmacie populaire du Mali," no. April, pp. 1-35, 2016, [Online]. Available: www.siapsprogram.org.

[3] Z. Vaezi, K. Shahgholian, and A. Shahraki, "A model for supplier selection based on fuzzy multi-criteria group decision making," Eur. J. Sci. Res., vol. 63, no. 1, pp. 63-72, 2011, doi: 10.5897/ajbm11.955.

[4] C. W. Corner, J. L. and Kirkwood, "Decision analysis applications in the operations research," Oper. Res., vol. 39, no. 2, pp. 206-219, 1991.

[5] S. L. Gebre, D. Cattrysse, and J. Van Orshoven, "Multi-criteria decision-making methods to address water allocation problems: A systematic review," Water (Switzerland), vol. 13, no. 2, pp. 1-28, 2021, doi: 10.3390/w13020125.

[6] H. Anysz, A. Nicał, Ž. Stević, M. Grzegorzewski, and K. Sikora, "Pareto optimal decisions in multi-criteria decision making explained with construction cost cases," Symmetry (Basel)., vol. 13, no. 1, pp. 1-25, 2021, doi: 10.3390/sym13010046.

[7] Z. Xu, "Approaches to multi-stage multi-attribute group decision making," Int. J. Inf. Technol. Decis. Mak., vol. 10, no. 1, pp. 121-146, 2011, doi: 10.1142/S0219622011004257.

[8] J. Chen, "SS symmetry for Monitoring the COM-Poisson Processes," 2020.

[9] G. Bohm and G. Zech, "Statistics of weighted Poisson events and its applications," Nucl. Instruments Methods Phys. Res. Sect. A Accel. Spectrometers, Detect. Assoc. Equip., vol. 748, no. 1, pp. 1-6, 2014, doi: 10.1016/j.nima.2014.02.021.

[10] M. N. Mokhtarian, "A note on 'extension of fuzzy TOPSIS method based on intervalvalued fuzzy sets,"” Appl. Soft Comput. J., vol. 26, pp. 513-514, 2015, doi: 10.1016/j.asoc.2014.10.013.

[11] V. H. Morales and J. A. Vargas, "Monitoring Aggregated Poisson Data for Processes with Time-Varying Sample Sizes," Rev. Colomb. Estadística, vol. 40, no. 2, pp. 243262, 2017, doi: 10.15446/rce.v40n2.59925.

[12] M. Shirinfar and H. Haleh, "Supplier Selection and Evaluation by Fuzzy Multi- Criteria 
Decision Making Methodology," Int. J. Ind. Eng. \&Production Res., vol. 22, no. 4, pp. 271-280, 2011.

[13] H. Garg, A. Keikha, and H. Mishmast Nehi, "Multiple-Attribute Decision-Making Problem Using TOPSIS and Choquet Integral with Hesitant Fuzzy Number Information," Math. Probl. Eng., vol. 2020, 2020, doi: 10.1155/2020/9874951.

[14] C. Utomo, N. A. Rahman, and A. Idrus, "Multi-Person Decision for Sustainable Design on Ibs Floor System Selection," J. Civ. Eng. Forum, vol. 21, no. 2, pp. 1227-1234, 2013, doi: $10.22146 /$ jcef.18928.

[15] J. Lu, G. Zhang, D. Ruan, and F. Wu, Multi-objective group decision-making: methods, software and applications. London: Imperial College Press, 2007.

[16] S. Saghafian and S. R. Hejazi, "Multi-criteria group decision making using a modified fuzzy TOPSIS procedure," Proc. - Int. Conf. Comput. Intell. Model. Control Autom. CIMCA 2005 Int. Conf. Intell. Agents, Web Technol. Internet, vol. 2, pp. 215-220, 2005, doi: 10.1109/cimca.2005.1631471.

[17] F. E. Boran, "An integrated intuitionistic fuzzy multi criteria decision making method for facility location selection," Math. Comput. Appl., vol. 16, no. 2, pp. 487-496, 2011, doi: 10.3390/mca16020487.

[18] W. Hadikurniawati and K. Mustofa, "Multicriteria group decision making using fuzzy approach for evaluating criteria of electrician," Int. J. Electr. Comput. Eng., vol. 6, no. 5, pp. 2462-2469, 2016, doi: 10.11591/ijece.v6i5.10946.

[19] H. K. Bhargava, S. Sridhar, and C. Herrick, "Beyond spreadsheets: Tools for building decision support systems," Computer (Long. Beach. Calif)., vol. 32, no. 3, pp. 31-39, 1999, doi: 10.1109/2.751326.

[20] E. J. Castellano and L. Martínez, “A web-decision support system based on collaborative filtering for academic orientation. Case study of the spanish secondary school," $J$. Univers. Comput. Sci., vol. 15, no. 14, pp. 2786-2807, 2009.

[21] L. S. Chen and C. H. Cheng, "Selecting IS personnel use fuzzy GDSS based on metric distance method," Eur. J. Oper. Res., vol. 160, no. 3 SPEC. ISS., pp. 803-820, 2005, doi: 10.1016/j.ejor.2003.07.003.

[22] N. Zhang, "Method for aggregating correlated interval grey linguistic variables and its application to decision making," Technol. Econ. Dev. Econ., vol. 19, no. 2, pp. 189-202, 2013, doi: 10.3846/20294913.2012.763071.

[23] W. R. W. Mohd and L. Abdullah, "Aggregation methods in group decision making: A decade survey," Inform., vol. 41, no. 1, pp. 71-86, 2017.

[24] K. Gompf, M. Traverso, and J. Hetterich, "Using analytical hierarchy process (AHP) to introduce weights to social life cycle assessment of mobility services," Sustain., vol. 13, no. 3, pp. 1-10, 2021, doi: 10.3390/su13031258.

[25] T. A.- Pachemska, M. Lapevski, and R. Timovski, "Analytical Hierarchical Process (AHP) method application in the process of selection and evaluation," Proceedings. Gabrovo Internatinal Sci. Conf. "UNITECH”. 21-22 Novemb. 2014, no. November, pp. 
373-380, 2014, [Online]. Available: https://www.researchgate.net/publication/276985609_ANALYTICAL_HIERARCHIC AL_PROCESS_AHP_METHOD_APPLICATION_IN_THE_PROCESS_OF_SELECT ION_AND_EVALUATION.

[26] R. W. Saaty, "The analytic hierarchy process-what it is and how it is used," Math. Model., vol. 9, no. 3-5, pp. 161-176, 1987, doi: 10.1016/0270-0255(87)90473-8.

[27] M. Brunneli, Introduction to the Analytic Hierarchy Process. 2015.

[28] V. Balioti, C. Tzimopoulos, and C. Evangelides, "Multi-Criteria Decision Making Using TOPSIS Method Under Fuzzy Environment. Application in Spillway Selection," Proceedings, vol. 2, no. 11, p. 637, 2018, doi: 10.3390/proceedings 2110637.

[29] E. Roszkowska, "Multi-Criteria Decision Making Models By Applying the Topsis Method To Crisp and Interval Data," Mult. Criteria Decis. Mak., vol. 6, no. Mcdm, pp. 200-230, 2011.

[30] A. Kobryń and J. Prystrom, “A Data Pre-Processing Model for the Topsis Method," Folia Oeconomica Stetin., vol. 16, no. 2, pp. 219-235, 2016, doi: 10.1515/foli-2016-0036.

[31] Z. Pavić and V. Novoselac, "Notes on TOPSIS Method," Int. J. Res. Eng. Sci., vol. 1, no. 2, pp. 5-12, 2013, [Online]. Available: https://www.researchgate.net/publication/285886027_Notes_on_TOPSIS_Method\%0A www.ijres.org.

[32] R. Rahim et al., "TOPSIS Method Application for Decision Support System in Internal Control for Selecting Best Employees," J. Phys. Conf. Ser., vol. 1028, no. 1, 2018, doi: 10.1088/1742-6596/1028/1/012052.

[33] A. Zadeh Sarraf, A. Mohaghar, and H. Bazargani, "Developing TOPSIS method using statistical normalization for selecting knowledge management strategies," J. Ind. Eng. Manag., vol. 6, no. 4, pp. 860-875, 2013, doi: 10.3926/jiem.573. 